\title{
Protein Efficiency Ratio of Pigeon Pea (Cajanus cajan) and Lima Bean (Phaseolus lunatus): A Sprague-Dawley Rat Growth Assay
}

\author{
Raycha Lei Concess M. Rama, ${ }^{1}$ Jillean Camille Q. Fabi, ${ }^{1}$ Generose Christy M. Mateo, ${ }^{1}$ Jewel Amor C. Catubag, ${ }^{1}$ \\ Lemuel L. Lozada, ${ }^{1}$ Rowel C. Malimban ${ }^{2}$ and Ernani R. Bullecer ${ }^{2}$ \\ ${ }^{1}$ College of Public Health, University of the Philippines Manila \\ ${ }^{2}$ Department of Nutrition, College of Public Health, University of the Philippines Manila
}

\begin{abstract}
Objective. This study has been conducted to determine the protein efficiency ratio (PER) of selected indigenous legumes, namely pigeon pea (Cajanus cajan) and lima bean (Phaseolus lunatus), as alternative protein sources.

Methods. Experimental diets (pigeon pea-based and lima bean-based) and control diet (casein-based) were formulated and standardized using proximate analysis to have $10 \%$ protein basal diet based on the Association of Official Analytical Chemists (AOAC) guidelines. Diets were given to corresponding groups (2 experimental, 1 control) using 30 albino Sprague-Dawley weanling rats aged 21 days old, over a 28-day growth assay.

Results. Results showed that the mean final weight and weight gain were significantly higher in rats fed with caseinbased diet ( $<<0.05$ for both parameters) compared to those fed with pigeon pea-based diet and lima bean-based diet. The two experimental groups showed no significant difference between their mean final weights and weight changes $(p=1, p>0.05)$. The PER of the casein $(3.37 \pm 2.71)$ is higher than that of the pigeon pea (1.87) and lima bean (1.32). These results can be attributed to the presence of anti-nutritional factors (ANFs) in the seeds of pigeon pea and lima bean. Reduced protein intake (due to bitter taste), toxicity, and interference with protein digestibility (through interaction with digestive enzymes) imparted by these ANFs can explain the weight loss among the experimental groups and consequently the low PER. Heat treatment done in the study were not adequate to remove the ANFs.
\end{abstract}

Conclusion. The study shows that pigeon pea and lima bean as protein sources alone are not as adequate and efficient in providing necessary protein requirements for weanling rats. Proper processing and treatment should be done to remove inhibitors of protein digestibility and quality.

Key Words: Protein efficiency ratio (PER), lima bean, pigeon pea, Sprague-Dawley rats

\section{BACKGROUND}

Part of this paper was presented at the 6th Seoul International Congress on Endocrinology and Metabolism, April 19-22, 2018, Seoul, South Korea.

Corresponding Author: Ernani R. Bullecer, RND, MPH, DrPH Department of Nutrition College of Public Health University of the Philippines Manila

625 Pedro Gil Street, Ermita Manila1000 Philippines

Telephone: +6325255858

Email: erbullecer1@up.edu.ph
Protein energy malnutrition (PEM) is the most common and prevalent form of malnutrition in the developing countries like the Philippines which is very evident among infants and children. ${ }^{1-2}$ In the National Nutrition Survey conducted in 2013 , it was found that 2 million children aged 0-5 years old are underweight, 3.1 million are too short for their age and around 0.8 million children are wasted. ${ }^{3}$ This can be attributed to a number of factors such as poverty, inadequate food and nutrient intake, and increasing population. ${ }^{1}$

Severe childhood PEM can be caused by a chronic, severely low energy and protein intake. This occurs when infants are given diluted formulas or non-nutritious and unsanitary complementary foods of low energy and micronutrient density. Infections including measles and 
diarrhea also affect the intake and absorption of protein and other nutrients. Malnutrition in children, especially those who are under the age of two years, results in significant morbidity, mortality, and impaired mental and motor development. The vicious cycle of malnutrition and infection has numerous adverse health effects including loss of appetite, malabsorption of nutrients, weakened immune responses and metabolic losses. ${ }^{4}$ The effects of these conditions can be furthermore intensified by social factors such as isolation, low income or poverty, limited knowledge in nutrition and/ or cooking, and alcohol and drug dependency. ${ }^{5}$

It has been perceived that animal sources give high quality protein. ${ }^{6}$ However, economic situations in the country do not provide easy accessibility of these foods. The present economic situation further aggravates the malnutrition problem with around 28 million Filipinos deprived of food to meet their daily nutritional requirements. ${ }^{7}$ In families belonging to the lower economic strata, capacity to buy daily intake of dairy or animal sources of protein seems to be a challenge. This results in people depending on staple and cheap food reserves. ${ }^{8}$

Legumes serve as the second most important plant source for human and animal nutrition. They are extremely rich in protein and can actually be used as an alternative to animal-based protein such as meat. In the developing countries, many legumes have been used for preparation of different dishes and have dominated the production and market chains. ${ }^{9}$ Studies on selected indigenous legumes have found adequate amount of proteins, essential amino acids and minerals, dietary fiber, and polyunsaturated fatty acids (PUFAs) in these specific food sources compared to the other common legumes. ${ }^{10}$ In addition, legumes encourage consumption since it improves the palatability of nutritionally adequate diets. Aside from its nutritional content, legumes adapt easily to different environments; thus, legumes provide the use of a highly nutritious and easy to grow plant, and at the same time improve agricultural productivity especially in the developing world. ${ }^{5}$

The protein efficiency ratios (PER) of some legumes are comparable to milk or beef, although different bean species may have different PER values. ${ }^{11}$ In a study conducted by Hove, King, and Hill using PER to assess protein quality of selected grain legumes, Lupinus angustifolius seed (with added methionine) was found to have growth and PER equal to reference casein and significantly superior to any of the other species (lupin species, phaseolus species, peas, and filed beans) when fed raw. However, after cooking, all beans and peas gave very good growth and PER values. ${ }^{12}$ On a separate note, it was found out that the vegetable protein mixture containing melon, cowpea, and soya as protein sources compared favorably with the control diet of a milk-based commercial product in terms of growth rate, PER and net protein ratio (NPR) and also ensured optimum nitrogen content in liver, kidney and muscle tissues. ${ }^{13}$ Thus, developing countries, especially in the rural areas, can benefit to the application of such mixture of vegetable proteins in the preparation of weaning foods.

Researches on pigeon pea include an analysis by the International Crops Research Institute for the Semi-Arid Tropics (ICRISAT) which compared two newly developed high-protein genotypes of pigeon pea for their nutritional quality characteristics and the results were compared with those of normal-protein genotypes. ${ }^{14}$ Fish farmers also benefit from legumes as a substitute to commercial feeds. In the study conducted by Solomon, Okomoda, and Onah, African catfish Clarias gariepinus fingerlings were fed with soaked C. cajan for partial replacement of soybean. It was concluded that soaking C. cajan seed for $24 \mathrm{hr}$ improved the nutritional profile to replace $20 \%$ of the soybean protein in the diet of $C$. gariepinus with no negative effect on growth and nutrient utilization. ${ }^{15}$

As for lima beans, some researches revolve around analyzing the bean's genetic structure. An example is the study by Bi et al (2002), with the aim to set up an in-situ conservation strategy for $P$. lunatus, they analyzed the genetic structure of 29 populations of lima beans in the Central Valley of Costa Rica in order to understand mechanisms controlling the genetic structure and population dynamics of the wild lima bean. ${ }^{16}$ Also, similar with the mentioned study on pigeon pea as fishfeed. Falaye et al (2014) determined Apparent Digestibility Coefficient (ADC's) of crude protein, lipid and energy in differently processed lima bean for utilization of $C$. gariepinus. At the end of the study, it was concluded that C. gariepinus can effectively digest boiled and toasted lima bean seed, with both treatments having better ADC's for protein, lipid, energy and phosphorus. ${ }^{17}$

Thus, this study was conducted to determine the protein efficiency ratio of selected underutilized Philippine legumes, namely pigeon pea (Cajanus cajan) and lima bean (Phaseolus lunatus), as alternative protein sources.

\section{METHODS}

\section{Study Design}

To determine the protein efficiency ratio of selected underutilized Philippine legumes, namely pigeon pea (Cajanus cajan) and lima bean (Phaseolus lunatus), as alternative protein sources, an experimental study was conducted.

\section{Study Setting}

The study was conducted in the laboratory of the Department of Nutrition, Lara Hall, College of Public Health, University of the Philippines Manila. Protocol was approved based on IACUC guidelines set by the University of the Philippines Manila.

\section{Study Subjects}

Thirty (30) Sprague-Dawley rats, Rattus norvegicus species (15 21-days weanling female rats and 15 21-days weanling male rats) were obtained from Food and Drug 
Administration (FDA), Alabang, Muntinlupa City. Their baseline weights were measured. The average weight of the rats in one group did not exceed by $5 \mathrm{~g}$ more than the average weight of rats in any other group. The rats were randomly assigned to their respective diets, ensuring that the mean initial weights had no significant difference. They were caged individually and labelled accordingly.

\section{Data Collection Procedures}

Prior to the start of the growth assay, the two experimental diets and control diet were formulated to have $10 \%$ protein basal diet based on the AOAC guidelines. The ingredients of the PER diet included $80 \%$ test protein and carbohydrate (corn starch), 10\% fat (corn oil), 2\% salt, 1\% vitamin mixture (pulverized Mosvit Gold) and 7\% fiber (C-lium). The ingredients were mixed together and the product was standardized using proximate analysis. The methods used in the proximate analysis for determining each component were as follows: protein content: Winkler modification of the Kjeldahl method; moisture content: the Sartorius moisture analyzer; fat content: Soxhlet method.

For 28 days, food and water were supplied ad libitum. Bowls of standardized diets were placed in their cages; each bowl was replaced with a new weighed amount of food every day, and the refuse was collected and measured to determine the total amount of food consumed.

Body weights of the rats were measured every two days using an analytical balance. All measurements were expressed in grams recorded to the nearest $0.01 \mathrm{~g}$.

At the end of the experiment, the rats were terminated using euthanasia consistent with the recommendations of the IACUC. Sprague-Dawley rats were sedated with Zoletil (dose of $50 \mathrm{mg} / \mathrm{kg}$ bodyweight) and injected (intracardiac) with an overdose of potassium chloride.

After the growth assay, the Protein Efficiency Ratio (PER), which estimates the protein quality in an in vivo assay by measuring weight gain per gram of protein consumed, was calculated using the formula:

$\mathrm{PER}=$ total weight gain of test group $(\mathrm{g}) \div$ total protein intake $(\mathrm{g})$

where protein intake $=$ food consumed $\mathrm{x}$ crude protein (in percent)

\section{Data Analysis}

Descriptive statistics was used to present the results of the study. Weight changes, food intake, protein intake, and
PER were presented as means and standard deviations, supplemented with graphical representations.

One-way ANOVA was used to compare the significant difference between the initial mean weights, final mean weights, and weight changes of the rats. Confidence level was set at 95\%. All statistical analysis was done using Stata software program version 13.0.

\section{RESULT}

\section{Proximate Analysis of the Diet}

The protein content of the diets was determined using the Winkler modification of the Kjeldahl method. The first mixing of the diets did not achieve the target protein. Recomputation was done through ratio and proportion. The second mixing of the diets achieved the desired level of protein for all groups: $11.84 \%$ for casein, $11.14 \%$ for pigeon pea, and $11.14 \%$ for lima bean. The moisture content of each diet was measured using a moisture analyzer. Moisture content of the pigeon pea-based diet (13.40\%) is higher than that of the casein-based (12.19\%) and lima bean-based (11.12\%) diets. Lastly, the fat content was determined using Soxhlet method. The lima bean-based diet (12.96\%) contained higher level of fat compared to the casein-based diet (11.20\%) and pigeon pea-based diet (11.43\%). Table 1 shows the summary of the proximate analysis data of the three diets.

\section{Food Intake}

As presented in Table 2, the total protein intake of the control (casein), experimental A (pigeon pea), and experimental B (lima bean) groups were $223 \mathrm{~g}, 118.86 \mathrm{~g}$, and $130 \mathrm{~g}$, respectively. An average of $22.3 \pm 12.12 \mathrm{~g}$ of protein was consumed by rats under the casein-based diet, $11.89 \pm$ $11.14 \mathrm{~g}$ for rats under the pigeon pea-based diet, and 13.0 $\pm 5.52 \mathrm{~g}$ for rats under the lima bean-based diet. ANOVA shows no significant difference between the protein intake of the rats $(p=0.0542, p>0.05)$. Since the $p$-value is close to 0.05 or is borderline significant, Bonferroni's test was done, and it confirmed that protein intake among the groups are comparable (lowest $\mathrm{p}$ value of 0.084 ).

Figure 1 shows the comparison of the total protein consumed by the rats fed with the three diets. Although rats under the control diet consumed more protein, ANOVA shows it did not significantly differ with the protein intake of the experimental groups.

Table 1. Summary of the protein, moisture, and fat content values of the diets obtained after the proximate analysis and standardization of the diets

\begin{tabular}{ccccc} 
& & \multicolumn{3}{c}{ Diet } \\
\cline { 2 - 5 } Composition & Casein (Control) & Pigeon Pea (Experimental A) & Lima Bean (Experimental B) \\
\multirow{3}{*}{ Protein } & 1st trial & $6.80 \%$ & $6.78 \%$ & $9.77 \%$ \\
& 2nd trial & $11.84 \%$ & $11.14 \%$ & $11.14 \%$ \\
& Moisture & $12.19 \%$ & $13.40 \%$ & $11.12 \%$ \\
& Fat & $11.20 \%$ & $11.43 \%$ & $12.96 \%$ \\
\hline
\end{tabular}




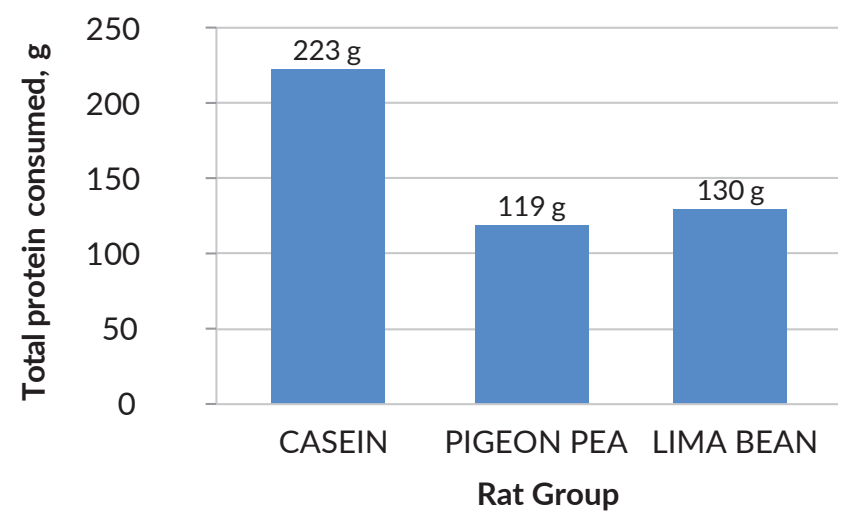

Figure 1. Total food and protein consumed by the control group and experimental groups.

\section{Weight Change}

Table 3 shows that among the rats in the casein group, the largest weight gain is $119.6 \mathrm{~g}$ and the lowest weight gain is $6.2 \mathrm{~g}$. The control group has an average weight gain of 75.08 $\pm 44.58 \mathrm{~g}$. The average weight gain of the male rats is 71.42 $\pm 49.58 \mathrm{~g}$; for the female rats, the average is $78.74 \pm 44.49 \mathrm{~g}$. T-test shows that there is no significant difference between the weight gain of male and female rats.

In the pigeon pea group, the greatest weight gain with $38.5 \mathrm{~g}$. The highest value of weight loss for this group was 12.1 g. The average weight gain of experimental group $\mathrm{A}$ is $8.95 \pm$ $16.49 \mathrm{~g}$. The average weight gain of the male and female rats are $11.58 \pm 19.66 \mathrm{~g}$ and $6.32 \pm 14.43 \mathrm{~g}$, respectively. Male and female rats do not differ with regards to weight change $(\mathrm{p}=0.5633, \mathrm{p}>0.05)$.

Table 2. Total food and protein consumed by the members of the control group and experimental groups throughout the 28-day assay

\begin{tabular}{|c|c|c|c|c|c|c|c|c|}
\hline \multicolumn{3}{|c|}{$\begin{array}{c}\text { Casein } \\
\text { (Control group) }\end{array}$} & \multicolumn{3}{|c|}{$\begin{array}{c}\text { Pigeon Pea } \\
\text { (Experimental group A) }\end{array}$} & \multicolumn{3}{|c|}{$\begin{array}{c}\text { Lima Bean } \\
\text { (Experimental group B) }\end{array}$} \\
\hline Rat Code* & $\begin{array}{c}\text { Food } \\
\text { consumed, } g\end{array}$ & $\begin{array}{l}\text { Protein } \\
\text { content, } \mathrm{g}\end{array}$ & Rat Code* & $\begin{array}{c}\text { Food } \\
\text { consumed, } g\end{array}$ & $\begin{array}{l}\text { Protein } \\
\text { intake, } \mathrm{g}\end{array}$ & Rat Code* & $\begin{array}{c}\text { Food } \\
\text { consumed, } \mathrm{g}\end{array}$ & $\begin{array}{l}\text { Protein } \\
\text { intake, } \mathrm{g}\end{array}$ \\
\hline MM1 & 267.2 & 29.77 & PM1 & 0.3 & 0.04 & LM1 & 99.5 & 11.08 \\
\hline MM2 & 16.6 & 1.85 & PM2 & 127.2 & 15.06 & LM2 & 130.1 & 14.49 \\
\hline MM3 & 176.8 & 19.70 & PM3 & 63.2 & 7.48 & LM3 & 128.8 & 14.35 \\
\hline MM4 & 231.3 & 25.77 & PM4 & 166.7 & 19.74 & LM4 & 0 & 0 \\
\hline MM5 & 161.2 & 17.96 & PM5 & 277.4 & 32.84 & LM5 & 160.5 & 17.88 \\
\hline MF1 & 321.1 & 35.77 & PF1 & 187.6 & 22.21 & LF1 & 100.5 & 11.20 \\
\hline MF2 & 270.3 & 30.11 & PF2 & 6.6 & 0.78 & LF2 & 179.3 & 19.97 \\
\hline MF3 & 14.4 & 1.60 & PF3 & 6.4 & 0.76 & LF3 & 90.8 & 10.12 \\
\hline MF4 & 248.2 & 27.65 & PF4 & 28.8 & 3.41 & LF4 & 145.4 & 16.20 \\
\hline MF5 & 294.7 & 32.83 & PF5 & 139.7 & 16.54 & LF5 & 132.1 & 14.72 \\
\hline Total & $2,001.8$ & 223.0 & Total & $1,003.9$ & 118.89 & Total & 1,167 & 130.0 \\
\hline
\end{tabular}

The first letter corresponds to Diet Group: $M=$ milk (casein); $P=$ pigeon pea; $L=$ lima bean. The second letter corresponds to sex of the rat: $M=$ male; $F=$ female. The third character corresponds to the ID number of rats of the same diet group and sex. For example: MM1 is the first male rat of milk group; PF5 is the fifth female rat of pigeon pea group.

Table 3. Individual, total weight gain and PER of the rats in the three groups

\begin{tabular}{|c|c|c|c|c|c|c|c|c|c|c|c|c|c|c|c|c|c|}
\hline & & $\begin{array}{r}\text { Cas } \\
\text { (Contro }\end{array}$ & $\begin{array}{l}\text { sein } \\
\text { l group) }\end{array}$ & & & & & $\begin{array}{r}\text { Pigec } \\
\text { xperimer }\end{array}$ & $\begin{array}{l}\text { on Pea } \\
\text { ttal group }\end{array}$ & & & & & $\begin{array}{r}\text { Lima } \\
\text { perimen }\end{array}$ & $\begin{array}{l}\text { Bean } \\
\text { tal group }\end{array}$ & & \\
\hline & Initial & Final & Weight & Protein & & & Initial & Final & Weight & Protein & & & Initial & Final & Weight & Protein & \\
\hline Code* & Weight, & Weight, & Change, & Intake, & PER & Code* & Weight, & Weight, & Change, & Intake, & PER & Code* & Weight & Weight, & Change, & Intake, & PER \\
\hline & g & $\mathrm{g}$ & g & g & & & g & g & g & g & & & $\mathrm{g}$ & g & g & g & \\
\hline MM1 & 36.4 & 149.7 & 113.3 & 29.77 & 3.81 & PM1 & 41.2 & 29.1 & -12.1 & 0.04 & -302.5 & LM1 & 42.4 & 32.5 & -9.9 & 11.08 & -0.89 \\
\hline MM2 & 5.1 & 28.2 & -6.9 & 1.85 & -3 & & 37.2 & 47.6 & 10.4 & 15.06 & & & 36.2 & 50.1 & 13.9 & 14.49 & 0.96 \\
\hline MM3 & 35.0 & 145.0 & 110 & 19.70 & 5.58 & PM3 & 39.8 & 39.0 & -0.8 & 7.48 & -0.11 & $\mathrm{LN}$ & 36.8 & 45.0 & 8.2 & 14.35 & 0.57 \\
\hline MM4 & 52.6 & 138.0 & 85.4 & 25.77 & 3.31 & & 37.8 & 59.7 & 21.9 & 19.74 & & & 36.1 & 36.1 & 0 & 0 & 0 \\
\hline MM5 & 33.4 & 88.7 & 55.3 & 17.96 & & & 39.4 & 77.9 & 38.5 & 32.84 & & & 34.4 & 55.8 & 21.4 & 17.88 & 1.20 \\
\hline MF1 & 38.6 & 158.2 & 119.6 & 35.77 & 3.34 & PF1 & 35.3 & 60.3 & 25 & 22.21 & & LF & 39.4 & 36.5 & -2.9 & 11.20 & -0.26 \\
\hline MF2 & 41.5 & 126.6 & 85.1 & 30.11 & 2.83 & PF2 & 34.2 & 28.5 & -5.7 & 0.78 & & & 41.2 & 66.3 & 25.1 & 19.97 & -0.66 \\
\hline MF3 & 37.1 & 43.3 & 6.2 & 1.60 & 3.8 & & 35.8 & 25.7 & -10.1 & 0.76 & & & 39.1 & 32.4 & -6.7 & 10.12 & 0.83 \\
\hline MF4 & 33.2 & 106.9 & 73.7 & 27.65 & 2.67 & PF4 & 39.1 & 31.2 & 7.9 & 3.41 & & LF & 35.6 & 49.0 & 13.4 & 16.20 & 0.46 \\
\hline MF5 & 35.5 & 144.6 & 109.1 & 32.83 & 3.3 & & 37.8 & 52.3 & 14.5 & 16.54 & & & 37.7 & 44.4 & 6.7 & 14.72 & 3.45 \\
\hline Total & 378.4 & 1129.2 & 750.8 & 223.01 & 3.3 & Total & 377.6 & 451.3 & 89.5 & 118.86 & & & 378.9 & 448.1 & 69.2 & 130.01 & 0.53 \\
\hline Ave. & 37.84 & 112.92 & 75.08 & 22.301 & 3.37 & Ave. & 37.76 & 45.13 & 8.95 & 11.89 & 0.75 & Ave. & 37.89 & 44.81 & 6.92 & 13.00 & 0.53 \\
\hline
\end{tabular}

The first letter corresponds to Diet Group: $M=$ milk (casein); $P=$ pigeon pea; $L=$ lima bean. The second letter corresponds to sex of the rat: $M=$ male; $F=$ female. The third character corresponds to the ID number of rats of the same diet group and sex. For example: MM1 is the first male rat of milk group; PF5 is the fifth female rat of pigeon pea group. 
In the lima bean group, the greatest weight gain with $25.1 \mathrm{~g}$. The highest weight loss of $9.9 \mathrm{~g}$. The average weight gain of experimental group B is $6.92 \pm 11.76 \mathrm{~g}$. There is no significant difference in the weight gain between male and female rats fed with lima bean-based diet. Weight changes are $6.72 \pm 12.15 \mathrm{~g}$ for males and $7.12 \pm 12.79 \mathrm{~g}$ for females.

Figure 2 shows that body weights of the rats in the control group exhibited a steady increasing trend throughout the period of animal experimentation. Same is true with the experimental diets, although weight gains were small compared to the control group. Weight change in the control group is significantly higher than those of the experimental groups $(\mathrm{p}<0.05)$. The weight gains of the rats in the pigeon pea-based and lima bean-based diets are comparable $(\mathrm{p}=1$, $\mathrm{p}>0.05$ ).

Two-way ANOVA also confirms that only the diet $(p<0.05)$ has a significant effect on weight gain, and not the sex of rats $(\mathrm{p}=0.9406)$. There is no interaction between the diets and sex of rats $(\mathrm{p}=0.8950)$.

\section{Protein Efficiency Ratio}

Table 3 also shows the PER of each member of the three groups. In the control group, the average PER is 3.37 \pm 2.71 , the largest PER of 5.58. Male rats have an average PER of $3.76 \pm 3.36$, whereas female rats have an average of $3.08 \pm 2.40$. In the pigeon pea group, the average PER is $0.75 \pm 1.56$, the largest PER of 2.32. The average PER of the male and female rats are $0.77 \pm 1.46$ and $0.72 \pm 1.85$, respectively. Lastly, in the lima bean group, the average PER is $0.53 \pm 0.93$, with the largest PER of 3.45. Male rats have an average PER of $0.58 \pm 1.11$; female rats have an average PER of $0.49 \pm 0.90$.

Figure 3 shows the PER of the three diets over the 4-week assay. The PER of casein is higher than that of the experimental groups (pigeon pea and lima bean). The PER of lima bean showed no drastic changes. Pigeon pea, on the other hand, presented an increasing PER to a value close to that of the lima bean.

Table 4. Summary of the mean weight change, mean protein intake, and PER of Sprague-Dawley rats

\begin{tabular}{cccc} 
Parameters & Control (Casein) & $\begin{array}{c}\text { Experimental A } \\
\text { (Pigeon Pea) }\end{array}$ & $\begin{array}{c}\text { Experimental B } \\
\text { (Lima Bean) }\end{array}$ \\
Average Initial Weight (g) & $37.84 \pm 5.74$ & $37.76 \pm 2.20$ & $37.89 \pm 2.58$ \\
Average Final Weight (g) & $112.92 \pm 45.82^{\mathrm{a}}$ & $45.13 \pm 17.37^{\mathrm{b}}$ & $44.90 \pm 10.99^{\mathrm{b}}$ \\
Live Weight Gain/Loss (g) & $75.08 \pm 44.58^{\mathrm{a}}$ & $8.95 \pm 16.49^{\mathrm{b}}$ & $6.92 \pm 11.76^{\mathrm{b}}$ \\
Average Food Intake (g) & $200.18 \pm 108.79$ & $100.39 \pm 94.14$ & $116.7 \pm 49.52$ \\
Protein Intake (g) & $22.30 \pm 12.12$ & $11.89 \pm 11.14$ & $13.00 \pm 5.52$ \\
Protein Efficiency Ratio & $3.37 \pm 2.71$ & $0.75 \pm 1.56$ & $0.53 \pm 0.93$ \\
Percent Survival (\%) & 80 & 50 & 80 \\
\hline
\end{tabular}

* Values in the same row with different superscripts are significantly different.

\section{Growth Curve of Rats}

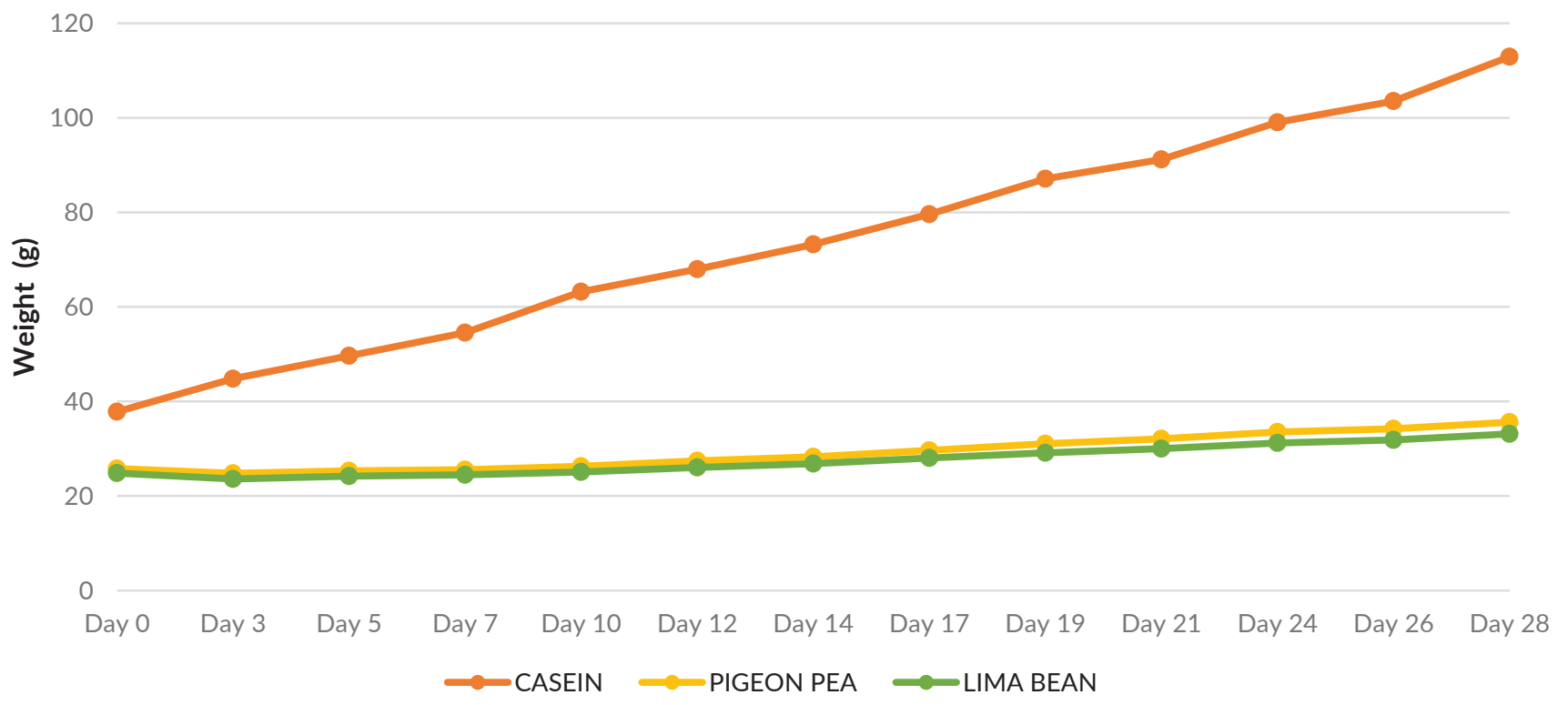

Figure 2. Growth curve of Sprague-Dawley rats subjected to the three diets. 


\section{Protein Efficiency Ratio of Casein, Pigeon Pea, and Lima Bean}

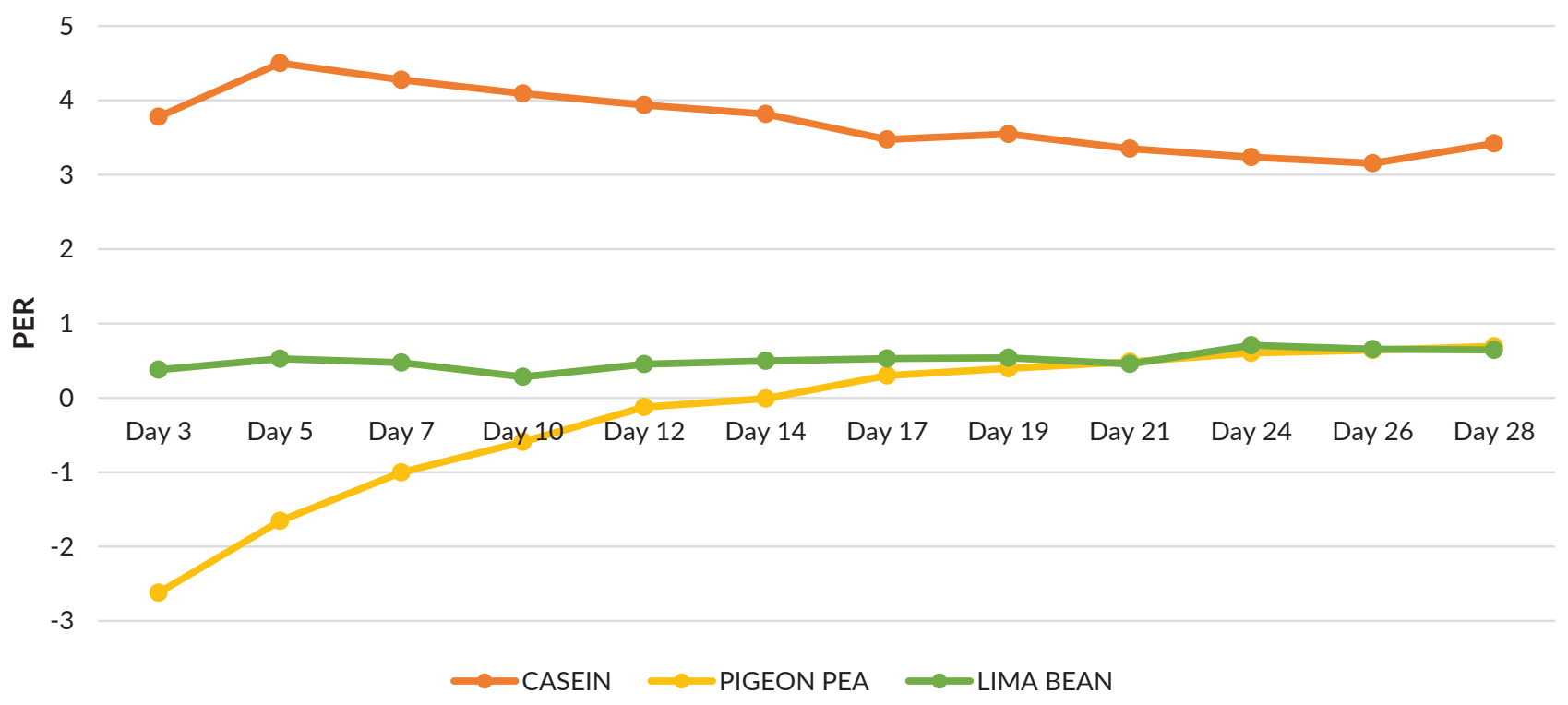

Figure 3. Comparison of the PER of the control and experimental groups.

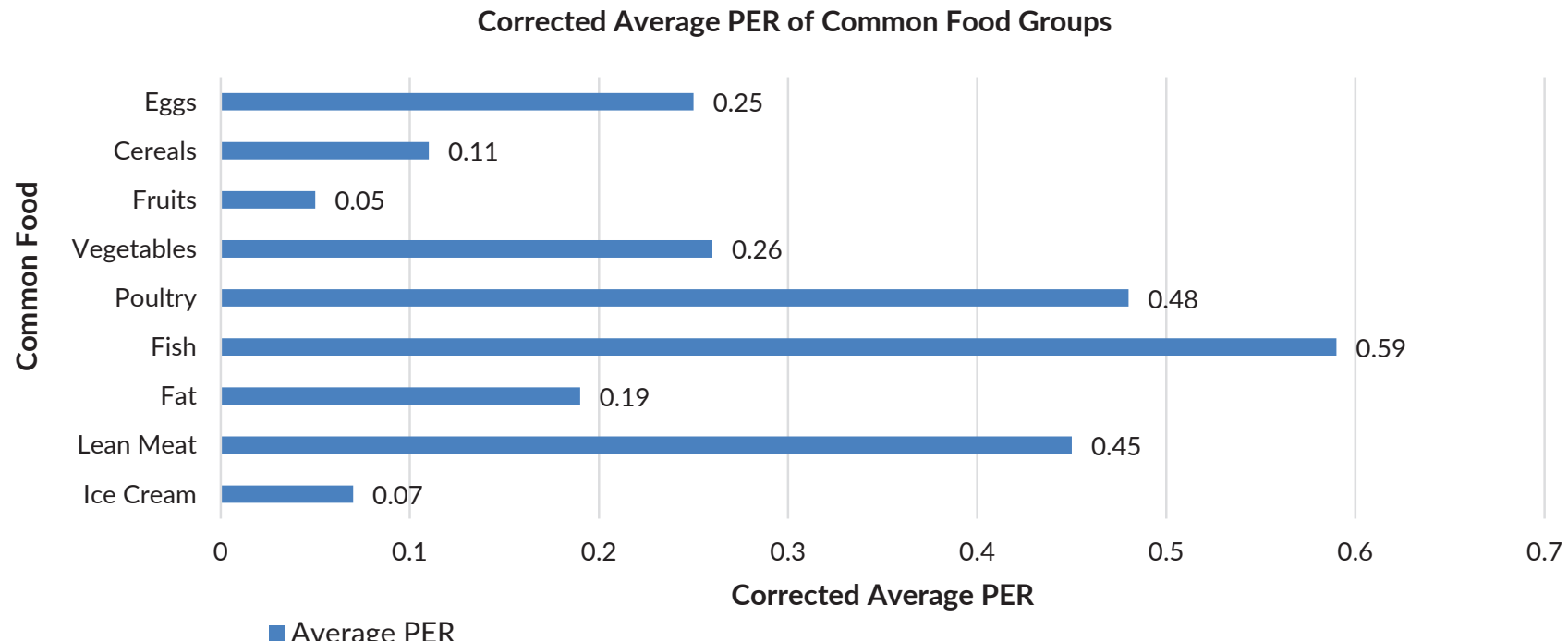

Figure 4. Corrected average PER of common food groups.

\section{Summary of Results}

Table 4 presents the summary for the 28-day feeding trial. At the start of the experiment, the mean initial weights showed no significant difference between the three groups $(p=0.997, p>0.05)$. Changes in body weights as an effect of protein source are illustrated in Figure 1. Protein intake does not vary between the groups. The mean final weight and weight gain are significantly higher in the control group compared to that of the experimental groups. The two experimental groups showed no significant difference between their mean final weights and weight changes.

The weight gain of the rats under the control diet is notable. During feeding trial, researchers also observed the pinkish skin among rats under the control diet, as compared with the relatively pale skin among rats fed with the experimental diets.

\section{DISCUSSION}

\section{Pigeon Pea Composition and PER}

Pigeon peas are moderate in calories and high in nutrients. Each cup has 209 calories, 11 grams of protein, 2.5 grams of fat and 8 grams of fiber. ${ }^{18}$ Pigeon peas are also an excellent source of magnesium, phosphorus, calcium and potassium and provides an adequate amount of iron, selenium and folate. ${ }^{19,20}$ 
The protein efficiency ratio of pigeon pea as tested in albino Sprague-Dawley rats is $0.79 \pm 1.56$, which is less than that of casein (control) which is $3.37 \pm 2.71$. Among the three diets, the pigeon pea-based diet yielded the lowest protein intake of $119 \mathrm{~g}$ as compared to $223 \mathrm{~g}$, and $130 \mathrm{~g}$ of the caseinbased and lima bean-based diets, respectively. This relatively low protein/feed intake can be attributed to the acidic taste of the pigeon pea seed coat affecting the palatability of the meal, as reported by Adeparasi in 1994. ${ }^{21}$ Reduced feed intake and the effects of the can explain the negative weight changes among the experimental group, and the death of 5 of 10 Sprague-Dawley rats.

\section{Lima Bean Nutritional Composition and PER}

Lima beans, sometimes called butter beans, are starchy yet buttery in texture. ${ }^{22}$ Lima beans, like many other legumes, are a good source of dietary fiber, and a virtually fat-free source of high-quality protein. The high fiber content of this legume prevents the rapid increase of blood sugar levels due to high amounts of absorptionslowing compounds ${ }^{22,23}$ making them low on the glycemic index, ${ }^{24}$ and high soluble fiber content. ${ }^{22,24}$ The soluble fiber absorbs water in the stomach, forming a gel-like mush. This in turn slows the carbohydrate absorption in the stomach. ${ }^{23}$ The fiber content also characterizes lima beans to be a good laxative and provides a decrease in the re-absorption of the colon. ${ }^{24}$

The lima bean experimental group has a protein efficiency ratio of $0.53 \pm 0.93$, the lowest compared to that of the pigeon pea and milk groups with $0.75 \pm 1.56$ and $3.37 \pm 2.71$, respectively, and an overall protein intake of $130 \mathrm{~g}$ - lower compared to the control group (223 g). This low food intake can be attributed to the bitter taste of lima beans, due to the relatively high amounts of tannins and cyanide making the diet unpalatable. In addition to this, the anti-nutrients found in the lima bean affects the digestive enzymes, decreases availability of free proteins, decreases the digestibility and absorption of these proteins, ultimately causing the decline of protein in the system of the rats. The low protein intake and digestibility in the lima bean group explain the low increase of weights and also the death of some of the rats, and ultimately the low PER.

\section{Anti-Nutritional Factors and Toxicity of Legumes}

As cited by Iorgyer, et al (2016), raw seeds of some legumes contain anti-nutritional factors (ANFs) such as tannins, trypsin inhibitors, amylase inhibitors, cyanide, lectins, etc. ${ }^{25}$ The activities of the digestive enzymes are inhibited by these ANFs thereby affecting the digestibility of the legume protein and causing digestive losses. ${ }^{26}$ In animals, complexes of dietary protein and digestive enzymes are formed with the presence of tannins. These complexes are not readily digestible, resulting in decreased feed consumption. On the other hand, trypsin inhibitor reduces the biological activity of trypsin. ${ }^{27}$ The presence of both tannin and trypsin inhibitor results in a decrease in the amount of free protein that can be readily absorbed.

One potentially toxic component of pigeon pea and lima bean are the cyanogenic glycosides. These are precursors of hydrogen cyanide, a systemic chemical asphyxiant; it interferes with the normal use of oxygen by cells in the body. ${ }^{28}$ Lima bean, on the other hand, stores the cyanide in active form, ${ }^{29}$ typically a cyanogenic glucoside called linamarin. ${ }^{30}$ Cyanide ions inhibit several enzyme systems, and they interfere with certain essential amino acids, suppressing or depressing growth. ${ }^{31}$ In some parts of Nigeria, pigeon peas have high concentrations of cyanogens as reported by Osagie (1998). ${ }^{32}$ Cyanogenic glycosides, oxalates, and trypsin inhibitor are unsafe at high concentrations in the blood and may lead to acute or chronic toxicity. ${ }^{33}$

Lectins are abundant in raw legumes and grains, providing the cellular integrity to prevent degradation when being ingested by herbivores and omnivores. ${ }^{34}$ In animals, lectins serve a wide range of biological functions, from regulation of cell adhesion to glycoprotein synthesis. However, because most animals, including humans, cannot digest lectins, antibodies are produced. Responses may vary and some may become intolerable and elicit an immune system response. ${ }^{35}$ They can be toxic, can disrupt the hormone balance, and deplete nutrient stores resulting in adverse physiological conditions such as growth depression, and sometimes it can even cause death. According to some studies, injecting lectins extracted from the immature seeds of seeds such as pigeon pea produced liver damage and death in young rats. ${ }^{36}$

\section{Effects of Processing of Legumes}

Soaking and traditional cooking methods such as boiling, autoclaving, and microwaving affect the composition, ANFs, flatulence factors and nutritional quality. ${ }^{35,37}$ All cooking treatments improved the in-vitro protein digestibility and protein efficiency ratio of most legumes. ${ }^{38}$ Most cooking treatments decreased the carbohydrate content, as well as the concentrations of lysine, tryptophan, total aromatic and sulfur-containing amino acids. ${ }^{37}$

Soaking and toasting eliminated trypsin inhibitor and lectin completely ${ }^{38}$ while the levels of phytin, tannin, and cyanide are reduced. ${ }^{39}$ On the other hand, autoclaving for 20 minutes was found to eliminate all the other anti-nutrients in lima bean except tannin. ${ }^{38}$ Extrusion is considered the best method to destroy protease inhibitors, amylase inhibitors, and hemagglutinating activity without significantly affecting the protein content of legumes. In comparison to soaking, dehulling, and germination, extrusion proved to be the most effective in improving protein and starch digestibilities. Reducing tannins, saponins, and trypsin inhibitors was achieved more efficiently through cooking treatments than germination, although germination was more effective in reducing phytic acid. ${ }^{25}$

Processing reduces or completely eliminates the activities of ANFs in legumes. However, it can also cause reduction 
in the concentrations of essential amino acids such as lysine and tryptophan, carbohydrate fractions, fat, minerals, and $\mathrm{B}$-vitamins. ${ }^{25}$ Overall, the decrease in the percentage of ANFs in both lima beans and pigeon peas is proportionally higher than that of the nutrients. ${ }^{40}$

In this study, the use of oven and toasting were the only kinds of heat treatment done on the legumes. With the use of dry heat and a relatively low temperature compared to other processing techniques, the anti-nutritive content of the selected legumes was possibly not eliminated, thereby affecting food intake and growth rate of rats. It is of vital importance to have a better understanding on the effects of processing in order to efficiently maximize the nutritional potential of legumes, leading to their wider use in the food industry.

\section{Effect of the Differences in Moisture Content}

The moisture content has an important influence in the assessment of the nutritional adequacy of the diet since it affects food intake, body weight gain, and protein efficiency utilization. Studies by Reussner, et al. (1964) showed that the dog food with the highest moisture level provided significantly lower body weight gains and protein efficiency utilization in rats, in comparison to the dry product. ${ }^{41}$ This is in line with the results of the study wherein the pigeon bean-based diet (diet with the highest moisture content) gave the lowest PER, and significantly lower weight gain than the control group. Studies by Keane et al. (1962), suggested that at higher protein levels, addition of moisture did not effectively improve protein utilization..$^{42}$ Moisture levels up to $50 \%$ may have increased food intake, but the weight gain and protein efficiency utilization remain unaffected. ${ }^{41,42}$

\section{Effect of Temperature}

One environmental condition that influences the food intake (as well as water intake) is temperature. It has always been noted that high temperatures will decrease the food intake. ${ }^{43}$ The study of Brobeck (1948) has shown that trend. The food intake of rats, which are acclimated to a temperature of $28^{\circ}$ to $29^{\circ} \mathrm{C}$, quickly decreases as the ambient temperature rises (from $18^{\circ}$ to $36^{\circ}$ ). In turn, they tend to lose weight when the ambient temperature during feeding increased to at least $32^{\circ} \mathrm{C} .4^{4}$

\section{Effect of Environmental Noise}

Another environmental condition that influences the food intake and body weight is environmental nose. Noise affects the behavior and can cause auditory as well as nonauditory effects in rats. It should be kept to a minimum since it can also cause stress. It was shown in a study by Turner et al. (2005) that the background noise level present in animal houses and laboratories can be enough to serve as stressors to these sensitive animals. ${ }^{45}$ The noise from the environment activates the autonomic nervous system, which in turn produces a stress response. This stress response leads to physiological characteristics similar to those triggered by other sensory stimuli. Furthermore, intense noise can lead to several alterations in the animal's body including changes with metabolism, food intake, body weight and behavior. ${ }^{46}$ This claim is further supported by the study conducted by Shafer (2006). It revealed that rats which are experiencing stress had decreased body weight and food consumption compared with those which are not. ${ }^{47}$

\section{Effect of Constant Weighing as Stress Factor}

Another possible reason for the decrease of food intake of the rats is stress. According to Baumans et al (2009), routine procedures, such as moving the animals out of the cages for weighing, food replacement, and cage cleaning, may promote acute stress response on laboratory animals and this daily stress exposure may reduce food intake (Marti et al, 1994). ${ }^{46,48}$

It is worth to note that all rats have undergone the same procedures during weighing and that the possible negative effects of constant weighing may be deem negligible when food intake patterns are taken into consideration.

\section{PER of Other Food Groups}

Protein energy ratio describes one of the basic aspects of nutritional quality of diets and their effects on weight gain, and must never be taken as a specific requirement for an individual. Experimental diets have a number of trace elements which may affect the rats' ability to digest them. As variations are almost unavoidable for different studies, the PER values of experimental diets are often reported relative to the casein control diet corrected to a 2.5 PER. ${ }^{49}$

$$
\text { Corrected PER Test Protein }=\frac{\text { PER Test Protein }}{\text { PER Casein Control }} \times 2.5
$$

In comparison from the diets used in the study, the corrected PER of some common food as reflected in Figure 4 are as follows: 0.07 for ice cream, $0.37-0.45$ for lean meat 0.13-0.19 for fat, $0.37-0.59$ for fish, $0.37-0.48$ for poultry, $0.11-0.26$ for vegetables in general, $0.02-0.05$ in fruits, $0.05-$ 0.11 in cereals, and 0.25 in eggs. ${ }^{50,51}$

\section{Limitations of the Study}

The general hydration of the rats would play a significant role in its weight gain. Unfortunately, the researchers only took note of it a few days into the study, thus having only partial data. There is also no guarantee that the amount recorded were the actual water intake of the rats, as the water bottles are prone to dripping. Also, moisture and fat levels were not standardized among the diets; variation in the moisture and fat content can also account for differences in weight gain and PER. The effect of environmental variables such as lighting, sound, temperature, and stress due to constant weighing on the consumption of the individual diets are not given particular attention, since the researchers did not include the measurement the stress level of the rats. Specific compositions of the protein sources which may reduce its 
palatability and/or digestibility are not analyzed and should be researched in future studies.

\section{CONCLUSION}

Limited knowledge has been established regarding the consumption of indigenous legumes, including pigeon pea and lima bean. This study determined the potential of pigeon pea and lima bean in promoting and maintaining growth and development among albino Sprague-Dawley rats. It aims to ascertain the potential of these indigenous legumes as alternative protein sources.

Literature notes the comparability of the protein contents of pigeon pea and lima bean with milk casein; however, results of this study showed that the PER of the experimental diets are lower than the control diet. With comparable protein intake between the groups, weight gain of the casein-based diet is significantly higher than those of the pigeon pea-based and lima bean-based diets. Pigeon pea and lima bean as protein sources alone may not be as adequate and efficient in providing necessary protein requirements for weanling rats. Further studies should be done to evaluate the potential effects of these legumes in human nutrition.

The researchers recommend that the anti-nutritional factors affecting protein digestibility, food intake, growth rate, and palatability be further evaluated. Adequate processing, namely heat treatment, soaking, and dehulling, is preferable to improve the palatability of the diet. Studies on the effects of processing on these legumes can be done to fully maximize the nutritional potential of these protein sources. The level of components of the diet, such as moisture and fat, should be the same. Future researchers should also consider the daily water intake, as the general hydration of the rats greatly affects weight gain. Also, environmental variables such as lighting, sound, temperature, and stress should be controlled. The researchers also suggest the use of negative control diets - consisting of the normal diets of the Sprague-Dawley rats, in order to take into consideration, the changes in weight due to the control diets themselves. Other protein evaluation methods such as biological value, protein digestibility, and amino acid score should be done.

\section{Statement of Authorship}

All authors have approved the final version submitted.

\section{Author Disclosure}

All authors have declared no conflict of interest.

\section{Funding Source}

No external funding.

\section{REFERENCES}

1. Horstkotte-Wesseler G. Socioeconomics of Rice-Aquaculture and IPM in the Philippines: Synergies, Potentials and Problems [Online].
1999 [cited 2015 Nov]. Available from https://books.google.com.ph/ books?id=MyXxLBS1fiUC\&printsec=frontcover\#v=onepage\&q\& $\mathrm{f}=$ false.

2. Department of Health, The Philippine Health System at a glance [Online]. 2011 [cited 2015 Nov]. Available from http://www.doh.gov. $\mathrm{ph} /$ sites/default/files/basic-page/chapter-one.pdf.

3. Save the Children. Sizing Up: The stunting and child malnutrition problem in the Philippines [Online]. 2015 [cited 2015 Nov]. Available from www.savethechildren.org.ph.

4. West K. Protein-Energy Malnutrition (PEM) and undernutrition causes, consequences, interactions, and global trends [Online]. 2006 [cited 2015 Nov]. Available from http://ocw.jhsph.edu/courses/ InternationalNutrition/PDFs/Lecture2.pdf

5. NHS.UK, Malnutrition - Causes - NHS Choices [Online]. 2015 [cited 22 November 2015]. Available from http://www.nhs.uk/Conditions/ Malnutrition/Pages/Causes.aspx.

6. Hiscock K. Best sources of protein [Online]. 2015 [cited 23 November 2015]. Available from http://www.bbcgoodfood.com/howto/guide/ best-sources-protein.

7. FAO.org. Nutrition country profiles: Philippines summary [Online]. 2015 [cited 201 Nov]. Available from http://www.fao.org/ag/AGN/ nutrition/PHL_en.stm

8. Kreiß1 A. Malnutrition in the Philippines - perhaps a double burden? [Online]. 1st ed. JEM; 2009 [cited 2015 Nov]. Available from http:// www.kup.at/kup/pdf/8113.pdf

9. Hildick E. Increasing protein, decreasing malnutrition [Online]. 2015 [cited 2015 Nov]. Available from http://www.scientiareview.org/ pdfs/284.pdf

10. Mendoza E. Biochemical and nutritional studies of Philippine indigenous food and forage legumes. Laguna: Institute of Plant Breeding, UPLB; 1989

11. Rockland, LB, Radke, TM. Legume Protein Quality. AGRIS. 1981; 35(3):79-82.

12. Hove E, King S, Hill, G. Composition, protein quality, and toxins of seeds of the grain legumes Glycine max, Lupinus spp., Phaseolus spp. Pisum sativum, and Vicia faba. Taylor \& Francis.1978; 21(3):457-62.

13. Fashakin, J.B., Awoyefa, M.B., Fürst, P. The application of protein concentrates from locally available legumes in the development of weaning foods. Z Ernährungswiss. 1986;25(4): 220-7.

14. Singh U, Jambunathan R, Saxena K, Subrahmanyam N. Nutritional quality evaluation of newly developed high-protein genotypes of pigeon pea (Cajanus cajan). J. Sci. Food Agr. 1990;50(2):201-9.

15. Solomon S, Okomoda V, Onah R. Nutritional profile of soaked Cajanus cajan (L.) Millsp. and its utilization as partial replacement for soybean meal in the diet of Clarias gariepinus (Burchell, 1822) fingerlings. J Appl Ichthyol. 2017;33(3):450-7.

16. Zoro Bi, I, Maquet, A, and Baudoin, J. Population genetic structure of wild Phaseolus lunatus (Fabaceae), with special reference to population sizes. Am. J. Bot. 2003; 90(6):897-904.

17. Omoike, A, Falaye, A, Orisasona, O. Apparent Digestibility Coefficient of differently processed lima bean (Phaseolus lunatus L.) for Clarias gariepinus juveniles. J. Fish. Aquat. Sci. 2014;9(2):75-84.0

18. SFGate.com. Are Green Pigeon Peas Healthy? [Online] No date [Cited 2017 July]. Available from http://healthyeating.sfgate.com/ green-pigeon-peas-healthy-6797.html

19. HealthBenefitsTimes.com. Pigeon peas facts and health benefits. [Online] 2017 [Cited 2017 July] Available from https://www. healthbenefitstimes.com/pigeon-pea/

20. USDA Nutrient Database. Pigeon Pea Nutritional Benefits. [Online] 2014. [Cited 2017 July] Available from http://afghanag.ucdavis.edu/b_ field-crops/other/isfieldpigeonpeanutritionafg.pdf

21. Adeparasi EO. Evaluation of the nutritive potential of cooked pigeonpea (Cajanus cajan) meal as a plant protein source for Clarias gariepinus finger lings. J. Agric. Technol. 1994; 2: 48-57.

22. The George Mateljan Foundation. Lima beans [Online]. 2016 [cited 2016 Mar]. Available from http://www.whfoods.com/genpage. php?tname $=$ foodspice $\&$ dbid $=59$ 
23. WebMD.com. Soluble and insoluble fiber: what's the difference? [Online]. 2015. [cited 2016 March]. Available from http://www. webmd.com/diet/features/insoluble-soluble-fiber

24. Mercola.com, What Are Lima Beans Good For? [Online]. 2016 [cited 2016 Mar]. Available from: http://foodfacts.mercola.com/limabeans.html

25. Iorgyer MI, Adeka IA, Ikondo ND, Okoh JJ. The Impact of boiling periods on the proximate composition and level of some antinutritional factors in pigeon pea (Cajanus Cajan) seeds. Publication of Faculty of Agriculture, Nasarawa State University. 2009;5(1):92-102

26. Yacout MHM. Anti-nutritional factors and its roles in animal nutrition. J Dairy Vet Anim Res. 2016; 4(1): 00107

27. Dreon MS, Ituarte $\mathrm{S}$ and \& Heras $\mathrm{H}$. The role of the proteinase inhibitor ovorubin in apple snail eggs resembles plant embryo defense against predation”. PLoS ONE. 2010; 5(12): e15059.

28. Centers for Disease Control and Prevention, The Emergency Response Safety and Health Database: Systemic agent: hydrogen cyanide. [cited 2016 March] Available from https://www.cdc.gov/niosh/ershdb/ emergencyresponsecard_29750038.html

29. Breyer M. 8 poisonous foods we commonly eat [Online]. 2013 [cited $2016 \mathrm{Mar}]$. Available from http://www.mnn.com/food/healthy-eating/ photos/8-poisonous-foods-we-commonly-eat/1-lima-beans

30. Tilton L. Beans! Beans! The poisonous fruit! [Online]. 2009 [cited $2016 \mathrm{Mar}$. Available from http://davesgarden.com/guides/articles/ view/2385/\#b

31. Sidduiq MW, Prasad K, Bansal V. Cyanogenic glucoside. In: Sidduiq MW, Prasad K, Bansal V, eds. Plant Secondary Metabolites, ThreeVolume Set. CRC Press; 2017.

32. Osagie AU. Antinutritional factors. In: Osagie AU, Eka OU, eds. Nutritional Quality of Plant Foods. Benin City, Nigeria: Post Harvest Research Unit; 1998. pp. 221-244

33. Nwaogu LA, Emejulu AA. Evaluation of the toxicity of cyanogens in a commonly consumed Nigeria legume pigeon pea (Cajanus cajan) seed and its biochemical effects in rabbits. Int. J. Biol. Chem. Sci. 2010; 4(5): 1435-41

34. Pusztai A, Ewen SWB, Grant G, et al. Antinutritive effects of wheat germ agglutinin and other $\mathrm{N}$-acetylglucosamine-specific lectins. $\mathrm{Br} \mathrm{J}$ Nutr. 1993; 70:313-21.

35. Frehner M, Scalet M, Conn EE. Pattern of the cyanide-potential in developing fruits: Implications for plants accumulating cyanogenic monoglucosides (Phaseoluslunatus) or cyanogenic diglucosides in their seeds (Linumusitatissimum, Prunusamygdalus). Plant Physiol. 1990;94(1):28-34

36. Srivastava RP. Antinutrients restraining biofortification. In: Singh U, Praharaj C, Singh S, Singh N, eds. Biofortification of food crops. New Delhi: Springer; 2016. pp. 333-48

37. Adeparusi EO. Effect of processing on the nutrients and anti-nutrients of lima bean (Phaseoluslunatus L.) flour. Nahrung. 2001;45(2):94-6

38. Hefnawy T. Effect of processing methods on nutritional composition and anti-nutritional factors in lentils (Lens culinaris). Annals of Agricultural Sciences. 2011;56(2):57-61.
39. Frehner M, Scalet M, Conn EE. Pattern of the cyanide-potential in developing fruits: Implications for plants accumulating cyanogenic monoglucosides (Phaseoluslunatus) or cyanogenic diglucosides in their seeds (Linumusitatissimum, Prunusamygdalus). Plant Physiol. 1990;94(1):28-34

40. Oke M, Sobowale S, Ogunlakin G. evaluation of the effect of processing methods on the nutritional and anti-nutritional compositions of two under-utilized Nigerian grain legumes. Pakistan J of Biological Sciences. 2013;16(24):2015-20.

41. Reussner GJ, Mazura J, Thiessen RJ. Effects of dietary moisture on the determination of the nutritional value of foods. Journal of Nutrition. 1964; 84:331-34. Available from jn.nutrition.org/ content/84/4/331.full.pdf

42. Keane KW, Smutko CJ, Krieger CH et al. 1962. The addition of water to purified diets and its effect upon growth and protein efficiency ratio in the rat. J Nutr. May; 77:18-22.

43. Krinke G. Administration: the laboratory rat [Online]. 2nd ed. [cited 2016 Mar]. Available from http://www.usp.br/bioterio/Artigos/ Procedimentos\%20experimentais/Administration_The_Laboratory_ Rat-By_George_J_Krinke-2.pdf

44. Brobeck, J.R. 1948. Food intake as a mechanism of temperature regulation. Yale J. Biol. Med. 20:545-52.

45. Turner J, Parrish J, Hughes L, Toth L, Caspary D. Hearing in laboratory animals: strain differences and nonauditory effects of noise. Comparative medicine. 2005;55(1):12. Available from: http://www. ncbi.nlm.nih.gov/pmc/articles/PMC3725606/

46. Baumans V, Castelhano-Carlos $\mathrm{M}$. The impact of light, noise, cage cleaning and in-house transport on welfare and stress of laboratory rats. Laboratory Animals. 2009;43(4):311-27.

47. Shafer S. Behavioral and biological effects of housing conditions and stress in male rats -- Relevance to heart disease [Online]. 2006 [cited 2016 Mar]. Available from http://www.dtic.mil/dtic/tr/fulltext/u2/ a458977.pdf

48. Martí O, Marti J, Armario A. Effects of chronic stress on food intake in rats: influence of stressor intensity and duration of daily exposure. Physiol Behav. 1994 Apr;55(4):747-53. Available from http://www. ncbi.nlm.nih.gov/pubmed/8190805

49. Nielsen SS, ed. Food Analysis, 3rd ed. New York: Plenum Publishers; 2003. Available from https://books.google.com.ph/books?id=8S1QLU $\mathrm{sDO} w \mathrm{~g}$ \& \& printsec $=$ frontcover $\# \mathrm{v}=$ onepage \&q\& $\mathrm{f}=\mathrm{false}$

50. FAO.org. Protein-Energy Ratios [Online]. 2016 [cited 2016 Mar]. Available from http://www.fao.org/3/contents/b4a3e2c4-4170-5bd9b6b7-c815205a212d/M2889E00.HTM

51. Millward D, Jackson A. Protein/energy ratios of current diets in developed and developing countries compared with a safe protein/ energy ratio: implications for recommended protein and amino acid intakes. Public Health Nutrition. 2004;7(03). 